\section{Power cuts fuel speculation}

\section{London}

THE future of Britain's only large-scale fossil fuel experimental power station is in trouble now that the Central Electricity Generating Board (CEGB) has decided to pull out of the project. The decision brings to three the number of major research projects from which it has withdrawn this year (see Nature 332, 384; 1988).

The decision will leave British Coal, the other major sponsor, high and dry unless the directors of the Pressurised Fluidised Bed Combustor (PFBC) at Grimethorpe in Yorkshire can find another source of funds to meet the shortfall.

The plant was intended to demonstrate coal combustion with minimum release of sulphur and other pollutants. Instead of scrubbing them from the exhaust gases, sulphur is removed by the addition of dolomite limestone to the burning coal.

A report on the first $£ 28$-million phase of the project appeared in last month's Journal of the Institute of Energy. To install turbines in the $80-\mathrm{MW}$ power station will require a further $£ 12$ million a year, which British Coal says it cannot afford by itself. The directors of the Grimethorpe project are this week due to meet representatives of the Paris-based International Energy Agency (IEA) to discuss alternative sources of funds.

Power stations built around the PFBC principles are claimed to be compact and versatile, burning various coal types at high pressure and relatively low temperature. Sulphur emission is said to be reduced by 90 per cent, while the stream of hot gases produced by the furnace can be used to drive a turbine, without the intermediary of a steam-raising plant, for an overall thermal efficiency of 41 per cent compared with the 38 per cent of a steam turbine system.

There has been substantial foreign interest in Grimethorpe, reflected in sponsorship from the US Department of Energy and the US Electric Power Research Institute. Plants based on the PFBC are under construction in the United States and in Sweden and are planned in Spain.

Ironically, the planned privatization of the British power generation industry may create a market for relatively small, efficient and environmentally friendly coalfired stations. But the Grimethorpe announcement comes after a great deal of speculation about the future of the CEGB and its $£ 162$ million-a-year research commitment. The British governments white paper (policy document) on the privatization of the industry did not mention research (see Nature 332, 299; 1988).

Henry Gee

\title{
Australian vice-chancellors opposed to government reforms
}

Sydney

THE heads of Australia's universities registered their opposition this week to the government's proposed reforms of Australia's higher education system, saying they will lead to bureaucratic intervention by government in the detailed affairs of the universities.

The reforms, put forward by the new Minister for Employment, Education and Training, John Dawkins, require that each institution prepare an 'educational profile' detailing how national interests will be served. A proportion of the education budget, initially 1 per cent, will be awarded by the government according to the relative merit of these profiles. The institutions are also expected to obtain a much greater proportion of their research funds from industry and to concentrate their efforts in areas of special expertise.

Legislation now before parliament will establish a National Board of Employ-

\section{UK medical research in morale crisis}

\section{London}

POOR pay and poor career prospects are seriously damaging the morale of medical researchers in Britain, according to a report from the House of Lords, published this week*. "It is not uncommon for a postgraduate research post to be advertised at a salary lower than would be paid a typist in many other fields, and moreover such posts are normally short-term contracts providing no career prospects whatever. Training grants are very low. These failings have to be remedied", the report from the House of Lords Select Committee on Science and Technology states.

But while poor pay and conditions are deterring many would-be medical researchers, the lack of adequately financed laboratories with sufficient technical support staff is an equally pressing problem. The committee calls for a greater proportion of grants to be given to long-term programmes rather than projects, and the allocation of $£ 25$ million towards the re-equipment of medical research laboratories.

The committee describes as unsatisfactory the funding of applied research in medicine and proposes the creation of a National Health Research Authority within the National Health Service which would take on a primary role in financing public health research and a part role in funding clinical research, but would not pay for basic research. Simon Hadlington Priorities in Medical Rescarch. HMSO. London. Ł6.30. ment Education and Training (NBEET) which will advise the minister directly. Under the board will come the Tertiary Education Council, responsible for recurrent funding for universities, and the Australian Research Council (ARC), responsible for research funding.

The Australian Vice Chancellor's Committee has now released a statement opposing this plan. The committee wants NBEET to be established as a statutory body, headed by a distinguished figure, so

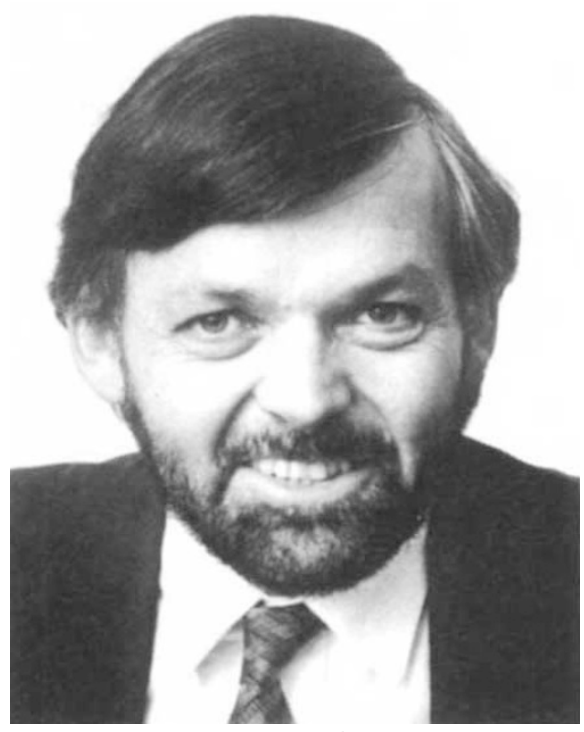

Dawkins - serving national interests

that the universities will be "cushioned against the whims of government".

The vice-chancellors are concerned that the government is trying to centralize control over research funds without providing criteria on which to make decisions and without saying how national economic and social priorities are to be determined.

Even though it would provide the higher education sector with an advocate in the minister's court, a statutory NBEET would not necessarily be in the best interests of higher education, according to Professor Don Aitkin, interim chairman of ARC, as it would distance the minister from the institutions. Aitkin believes the minister should be allowed to govern.

The vice-chancellors also called for funding for higher education to be maintained at 1 per cent of gross domestic product (GDP). That implies annual growth of 3 per cent, well above the present figure of 0.99 per cent. Here Dawkins agrees, saying that, "what's inevitable is that the amount devoted to higher education in future will be at least 1 per cent (of GDP)". But Dawkins did not go so far as to promise to keep it there with government funds.
Charles Morgan 